\title{
The Influence of "Ubrug" Sociodrama Technique toward Students Self-Efficacy
}

\author{
Siska Permatasari ${ }^{*}$, Rahmawati $^{2}$, Raudah Zaimah Dalimunthe ${ }^{3}$ \\ ${ }^{1,2,3}$ Department of Guidance and Counseling, Faculty of Teacher Training and Education, \\ University of Sultan Ageng Tirtayasa, 42117 \\ *) Corresponding author: siskapermatasari1796@gmail.com
}

\begin{abstract}
The study's purpose is to know the effects of the 'ubrug' sociodrama technique 'on a student's self-efficacy and the effectiveness or failure of a given technique. This type of research is a preexperimental study using one group pre-post test design. The population taken as many as 112 students with the characteristics of class IX students (a, b, and c), aged 14-16 years, have low self-efficacy with a lack of self-confidence and slightly more closed behavior, are willing to take the time to fill out the questionnaire given, and students must be committed to the "Ubrug" sociodrama treatment. Obtained a sample of 15 students with a purposive sampling technique. The data collection method uses a self-efficacy questionnaire consisting of 34 statement items with a reliability value (count) of 0.896 . The results of giving a post-test prove that there is an increase in the results obtained by students significantly. It can be concluded that the Sociodrama Technique "Ubrug" can increase the self-efficacy of IX grade students at SMPN 5 Kota Serang.
\end{abstract}

Keywords: self-efficacy, "ubrug" sociodrama technique

\begin{abstract}
Abstrak
Tujuan penelitian untuk mengetahui pengaruh diberikan teknik sosiodrama "Ubrug" terhadap efikasi diri siswa serta efektif atau tidak nya teknik yang diberikan. Jenis penelitian yang digunakan adalah pra-eksperimen dengan menggunakan one group pre-post test design. Populasi yang diambil sebanyak 112 siswa dengan karakteristik siswa kelas IX (a, b dan c), berusia 14-16 tahun, memiliki efikasi diri yang rendah dengan kurangnya rasa percaya diri serta perilaku yang sedikit lebih tertutup, bersedia meluangkan waktunya untuk pengisian kuesioner yang diberikan, dan siswa harus berkomitmen untuk treatmen sosiodrama "Ubrug". Diperoleh jumlah sampel sebanyak 15 siswa dengan teknik purposive sampling. Metode pengumpulan data menggunakan angket efikasi diri yang terdiri dari 34 item pernyataan dengan nilai reliabilitas (rhitung) sebesar 0.896. Hasil pemberian post-test membuktikan bahwa adanya peningkatan hasil yang diperoleh siswa secara signifikan. maka dapat disimpulkan bahwa Teknik Sosiodrama "Ubrug" dapat meningkatkan efikasi diri siswa kelas IX SMPN 5 Kota Serang.
\end{abstract}

Kata kunci: efikasi diri, teknik sosiodrama "ubrug" 


\section{Introduction}

Education is a system that consists of three components, namely inputs (students and teachers as educators), processes that are influenced by the environment and teaching instruments, and outputs or outcomes. Education is an important thing in the life of every individual. Things explained in Law No. 20 of 2003, concerning the National Education System (Sisdiknas) CHAPTER 1, Article 1, Page 5, which explains that education is a conscious and planned effort to enliven the atmosphere of learning and the learning process so that students actively develop potential himself to have religious, spiritual strength, self-control, personality, intelligence, noble character, and the skills needed by himself and society, nation, and country.

Adolescence is a transition from childhood to adulthood. According to Wirawan and Eko (1991), the age limit for adolescents according to WHO is 10-20 years, namely early teens 10-14 years and late teens $15-20$ years, while the adolescent age limit for Indonesian people uses 11-24 years and not married. According to Hurlock (1980), there are some characteristics of students in early adolescence, namely adolescence as a period of change when physical changes occur rapidly, changes in behavior and attitudes also develop rapidly. Changes that occur, such as changes in emotions, changes in the body, changes in interests and behavior, and teens are more ambitious about something. Hurlock (1980) also explains that early teens are usually ambitious about something, but not a few students who are less sure of their abilities. The surrounding environment strongly influences increased and reduced prejudice during adolescence. If a teenager is in an environment that is individually supported by friends deemed unsuitable, then a teenager will not care about other people around even difficult to judge himself how well he can function in certain situations. The behavior of students who are not sure of their abilities is very influential in their lives because humans live in a social environment, so if the behavior is not immediately addressed, it is feared that it will damage the morale of the nation's children.

One thing that needs to be improved in students is self-efficacy. According to Bandura (1986), self-efficacy is an individual's trust in his ability to succeed in doing something. Self-efficacy needs to be owned by every student because it is one of the most influential aspects of knowledge about oneself in daily human life. Self-efficacy is the belief that someone can master the situation and get positive results. Self-efficacy is a construct proposed by Bandura based on social cognitive theory. In his theory, Bandura (1997) states that human activity is a reciprocal relationship between individuals, the environment, and behavior.

Bandura (1997), in social cognitive theory, explains that students' low selfefficacy will cause increased anxiety and avoidance behavior. Individuals will avoid activities that can aggravate the situation, threats do not cause this, but because they feel they cannot manage the aspects that are at risk. Bandura (1997), in social cognitive theory, explains that the low self-efficacy of students will cause increased anxiety and avoidance behavior. Individuals will avoid activities that can aggravate the situation, threats do not cause this, but because they feel they cannot manage the aspects that are at risk. Self-efficacy is one of the potentials in human cognitive factors because it is very influential on every human being's behavior. Self-efficacy also illustrates how people feel, think, motivate themselves, and behave. Furthermore, Bandura and Wood (1989) add that belief in one's capabilities to mobilize the motivation, cognitive resources, and courses of action need to meet given situational demand. 
According to Gredler (2009), self-efficacy is an individual's belief in ability he has to organize and execute an action in achieving a goal. Self-efficacy affects individuals in cognitive processes in the form of goals created in mind, motivation processes in the form of impulses to act, affective processes in the form of anxiety, and the selection process in the individual selection of situations conditions. Meanwhile, according to Alwisol (2009), self-efficacy is a self-perception of how well the self can function in certain situations. Self-efficacy is related to the belief that the self can perform the expected actions. Alwisol (2009) also added that self-efficacy could be obtained, modified, enhanced, or reduced through one or a combination of four sources, namely the experience of mastering something (performance accomplishment), vicarious experiences, social persuasion, and emotional physiology (emotional physiological) states).

Meanwhile, Schults (1994) found that self-efficacy is our sense of adequacy, efficiency, and ability to cope with life. Next, Lahey (2004) defines self-efficacy as the perception that someone can do something important to achieve his goals. This includes a feeling of knowing what to do and also being emotionally able to do it.

Based on the results of information sources obtained from Prasetya (2019) regarding cases in Serang City, when they were going to conduct a sudden inspection (inspection) to the Serang City Regional Environment Office (DLHD) in the Kepandean environment, the Mayor of Serang caught many students hanging out at stalls during school hours. The number one person in Serang City immediately asked them to return to their respective schools. The behavior of students with low efficacy certainly affects student achievement in school. If left unchecked, the attitudes of students with low efficacy will continue at every level of education that will be passed.

Research conducted by Anggara, Yusuf, and Marjohan (2016) proves that group guidance with modeling is effective against increasing self-efficacy in facing exams. Students also have a higher motivation than before to be able to face the end of the year exams. Generalization shows that students have self-efficacy in a wider range of activities in academic activities in various situations. Another study was conducted by Syaefullah and Syefullah (2015), who found which meant that students had confidence in their abilities, were able and confident in solving problems.

Furthermore, the role of Guidance and Counseling (BK) teachers in improving students' self-efficacy are low at SMP Negeri 5 Serang City, Kasemen District. Teacher guidance and counseling have an important role in the development of students in school, helping, and providing solutions to problems experienced by students. A teacher must be able to balance his role in front of students so that students feel comfortable and want to share their stories with their problems. In this case, the treatment that will be used is to provide group guidance services using the sociology technique "Ubrug". This is expected to improve students' self-efficacy so that they can be more confident of their potential.

According to Blatne (2019). Sociodrama assumes that certain groups and groups are influenced by social roles and cultural levels of certain communities. Sociodrama as a basis for the development of psychodrama methods, which is a method or technique based and aims to catalyze social conflicts in general that occur and develop in group interactions that are personal and group, by playing roles using theatrical approach (drama). Meanwhile, according to Sanjaya (2012), the use of sodiodrama techniques is considered capable of solving problems related to social phenomena or problems involving relationships between humans. Sociodrama is used to provide understanding 
and appreciation of social problems and develop students' ability to solve them. Meanwhile, according to Winkel (1993) suggests that sociodrama is a dramatization of various problems that can arise in association with other people, including conflicts that are often experienced in social relationships. This is in line with what was expressed by Romlah and Tatiek (2013) that sociodrama technique is one of the role-plays aimed at solving social problems that arise in human relations. Sociodrama is seen as one of the right methods to reduce aggressive behavior. It allows students to play a particular role in social problem situations and teaches ways to behave in relationships between human beings so that students can directly experience the experience gained through their role. This technique is seen as one of the right techniques to reduce low self-efficacy because it allows students to play a certain role in social problem situations and teaches ways to behave in relationships between people so that students can directly experience the experience gained through its role.

According to Darajat (2011) the purpose of sociodrama technique is that students are not awkward in dealing with social situations, eliminate feelings of shame and inferiority that are misplaced, educate and develop abilities, express opinions in front of their friends, learn how to share responsibilities, and get used to being able to accept and respect the opinions/feelings of others. Then the other experts explain that sociodrama aims to provide an opportunity for members to deepen sensitivity and insight into social problems that 1) increase social understanding; 2) increasing knowledge about themselves and the participation counselees; 3) enhance emotional relationships or catalyze the role of many people by expressing the counselee's feelings about someone or someone else (Eckloff and Maurine, 2006).

This is in line with Humeira (2014) research that group guidance services with role-playing techniques can improve students' self-efficacy in learning. In this research, there are things that make a difference in previous studies, namely by using the sociodrama technique "Ubrug". This technique is very helpful in experimental research so that the results are seen before and after treatment is given. This aims not only to improve students' self-efficacy but also to preserve art in Banten. So that researchers can improve student self-efficacy through the provision of treatments and also preserve culture. According to Seha, Bachtiar, Oktaviantina, Rukmini, and Sehabudin (2014), ubrug is a people's theater that has a function as a medium for delivering information or messages to the public on the description of the reality of community life. Ubrug is also able to display the characteristics of heterogeneous people in the media play. Content in ubrug is expected to be able to provide information relating to the description of a society in general.

In this research, some things make a difference in previous studies, namely by using the sociodrama technique "Ubrug". This technique is very helpful in experimental research so that the results are seen before and after treatment is given. This aims not only to improve students' self-efficacy but also to preserve art in Banten. So that researchers can improve student self-efficacy through the provision of treatments and also preserve culture.

Therefore it is necessary to limit the problem so that researchers are more focused on exploring and overcoming existing problems. So in the research, the discussion will focus on the Influence of "Ubrug" sociodrama technique toward students' selfefficacy-efficacy (A Pre-Experimental Study of IX grade students at SMP Negeri 5 Kota Serang). 


\section{Methods}

\section{Participant}

The research method used in this study is quantitative, using a pre-experimental research approach. According to Sugiyono (2017), quantitative methods based on the philosophy of positivism are used to examine populations and certain samples, with generally random sampling techniques, data collection using research instruments, quantitative or statistical data analysis with the aim to test the hypotheses that have been set.

Meanwhile, according to Yusuf (2014), pre-experimental, namely experimental research, which in principle only uses one study group without using a control group, and respondent taking is not randomized. The type of pre-experimental research used by researchers is the One Group Pre-test Post-test Design because measurements are carried out twice, before being treated (O1), called pre-test and measurement after being treated $\left(\mathrm{O}_{2}\right)$ is called post-test. The design can be described as follows:

\begin{tabular}{|lll|}
\hline $\mathrm{O}_{1}$ & $\mathrm{X}$ & $\mathrm{O}_{2}$ \\
\hline
\end{tabular}

Figure 1 One group pre-test and post-test design

$$
\text { Explanation : } \begin{aligned}
\mathrm{O}_{1} & =\text { Pretest } \\
\mathrm{X} & =\text { Treatment } \\
\mathrm{O}_{2} & =\text { Post-test }
\end{aligned}
$$

This research was conducted at SMP Negeri 5 Kota Serang. The research implementation process lasted for two months using data collection techniques in the form of a questionnaire method. Researchers use the questionnaire method as a method of collecting data for pre-test and post-test. The questionnaire method will be obtained interval data, which is interpreted in data analysis.

According to Sugiyono (2017), the population is a generalization area consisting of objects/subjects with specific quantities and characteristics applied by researchers to be studied and then drawn conclusions. The population is not just the number of objects or subjects studied but includes all the characteristics or properties possessed by the subject or object. The characteristics of the population taken in this study are students aged 15 years, have low self-efficacy with a lack of self-confidence, and behavior that is a little more closed, and are willing to follow the exercises to undergo treatment.

Researchers took samples by using a purposive sampling technique. According to Sugiyono (2017), the sample is part of the number and characteristics possessed by the population. This sampling must be done in such a way as to obtain a sample that can truly describe the actual or representative population (representing). The size of the sample members is based on the Gay and Diehl theory of (1992) experimental research can be provided with a minimum number of 15 elements per group. Based on that, research will take a number of subjects for the experimental group of 15 people. The subjects are selected randomly from a number of 3 classes with low self-efficacy. The sample to be used by researchers has a provision, students of IX grade students at SMP Negeri 5 Kota Serangwho have low levels of self-efficacy 


\section{Measures}

The operational definitions of the two variables taken by the researcher are selfefficacy and sociodrama techniques. Self-efficacy is one's belief in being able to perform a given task or an achievement that signifies his level of ability. Self-efficacy is measured using a self-efficacy scale consisting of dimensions/aspects of the level, aspects of the strength, and aspects of the generalization. The scale consists of 34 item sand Cronbach alpha of 0.896. Sociodrama technique is a group guidance technique that provides opportunities for students to dramatize and solve social problems related to attitudes, behavior that occurs in daily life so that through this sociodrama technique students gain experience and understanding of social problems and how to solve the problem. There are three stages of implementing sociodrama techniques: a) preparation of simulation, b) implementation of simulation, and c) closing.

\section{Analysis}

After the data is collected, an analysis using SPSS (Statistical Package for Social Science) version 20 is then performed using the Cronbach alpha statistical test. The instrument reliability results can be seen that Crombach's alpha with 34 statement items, obtained a reliability value (count) of 0.896 . This means that the instrument is able to produce scores on each item consistently and is suitable for use in research.

According to Sekaran, Uma, and Bougie (2017), data sources can be obtained from primary or secondary sources. But in this study, which examined data sources are primary data that is kuantiatif of disseminating questionnaires and direct observation by the parties related to the research. Analysis of the data used in the form of pre-test and post-test with the same questionnaire contents consisted of 34 items. The pre-test results will be seen in students who have low grades then given treatment eight times, and then students will be given a questionnaire in the form of a post-test to determine the differences before and after being given treatment.

In this study, researchers provided instruments in the form of questionnaires about self-efficacy variables in which there are researchers' references in making statements. Experts have considered the results of the questionnaire in the form of aspects or dimensions of the self-efficacy variable. These aspects or dimensions are, according to Bandura (1997), in the form of levels, strengths, and generalizations. The following explanation is, according to Mahmudi and Suroso (2014).

1. Level Aspects

The level aspect is a problem related to the degree of difficulty of the task when individuals feel able or not to do it. The level of difficulty referred to by Bandura (1997) is the level of difficulty of the tasks faced by students. If students are confronted with tasks arranged according to their level of difficulty, students' selfefficacy may be limited to tasks that are easy, moderate, or even include the most difficult tasks with the limits of perceived ability to meet the demands of the behavior required in each level. The higher the level of difficulty of the task, the higher the demands of his self-efficacy. So students with low self-efficacy will tend to avoid tasks that have a high level of difficulty. Aspects of the level in research are divided into two indicators, namely self-understanding and understanding the level of difficulty of the task. The description is as follows:

a. Self-understanding

Self-understanding exists before the individual understands the level of task to be faced. Self-understanding oriented to the level of self-ability in completing a 
task challenge and self capacity from what has learned previously. For example, when students have a Math assignment, they feel they have not understood the assignment because so far, they have not understood mathematics.

b. Understanding the level of difficulty of the task

Understanding the level of difficulty of the task indicates students understand and be able to clarify the task according to the level of difficulty. Students will try to do certain tasks that are perceived to be implemented, and students will avoid perceived behavioral situations beyond their ability. Task perception is formed from students' experiences in completing assignments as well as from the level of their ability to complete assignments. For example, when students understand that they are not able to complete mathematical tasks, students choose to work with their friends rather than students not doing math tasks. Choosing to do assignments with friends is the attitude students plan to complete the task.

2. Strength aspects

This aspect relates to the level of strength of an individual's beliefs or expectations regarding his abilities. According to Bandura (1997) explains that this aspect is related to the strength of students' confidence in their abilities. Unsupportive experiences easily sway weak beliefs. Conversely, firm beliefs encourage individuals to persevere in their business. This dimension is usually directly related to the level dimension, namely the higher the level of difficulty of the task, the weaker the perceived confidence to complete it.

a. Individual beliefs

Confidence refers to the degree of stability of the individual against the beliefs or expectations made. Confidence arises from not only students but also encouragement from outside that affects the level of confidence in verbal persuasion or the experience of achieving others that make students confident. An example would be the inability of students to complete math assignments. This belief can be influenced from within him or verbal persuasion from others to be able to complete mathematical tasks.

b. Hope

I hope as something that can be formed in students and can be used as a step to make changes. For example, students who believe that students can complete mathematical tasks both beliefs that are formed from within and from outside themselves, students have expectations of the final value or completion of mathematical tasks that students do. The value or the final result is the hope of students in completing an achievement in themselves.

3. Generalization aspects

Self-efficacy can be demonstrated by the level imposed on students, which later there will be challenges with different levels to succeed. The generality aspect is related to the Level aspect, which is the wide scope of behavior believed by students to be able to be carried out. The aspect of generality in research divided into two indicators, namely multiple tasks and cross-cutting. The following explanation:

a. Double duty

Multiple tasks in the dimension of generality that is, students complete two or more tasks at a time. The scope of tasks can be in one field or different fields. 
Self-efficacy can usually foster a sense of confidence that they can solve different obstacles simultaneously. For example, when students can complete mathematical tasks at one time, they are sure to be able to complete physics tasks at one time or complete math tasks and study simultaneously.

b. Cross-cutting

Cross-cutting in the aspect of generality indicates that students can complete tasks outside the field that students have completed. Cross-cutting, in this study, signifies that students can complete tasks outside the field of ability that students believe can be completed. For example, when students can complete subject assignments well and get results according to expectations, students will be confident of being able to complete assignments from different fields, such as participating in non-academic competitions. Students believe in being able to solve academic and non-academic challenges at the same time.

Researchers also get the results of reflection during the research process at school, and the results show that students always have a large enthusiasm when given treatment. However, not a few still have shame and nervousness when the prefix begins. Students are also very happy and feel that there is always experience when given treatment until the end of the process of giving sociodrama "Ubrug" techniques. Students become more comfortable and able to develop the roles obtained so that the self-efficacy of IX grade students at SMP Negeri 5 Kota Serang.

\section{Findings}

From the results of research that has done, there are scores obtained from the spread of student self-efficacy scale with the number of the population selected. The following are the self-efficacy of IX grade at SMP Negeri 5 Kota Serang obtained from collecting data on 112 students.

Table 1 Self-efficacy

\begin{tabular}{lrrr}
\hline Category & Criteria & Respondents & Percentage (\%) \\
\hline Very high & $111.5-136$ & 7 & 6.2 \\
High & $86-110.5$ & 90 & 80.3 \\
Low & $60.5-85$ & 15 & 13.4 \\
Very low & $34-59.5$ & 0 & 0 \\
\hline Totals & & 112 & 100 \\
\hline
\end{tabular}

Looking at Table 1 shows that the self-efficacy of students included in the low category of 15 students or $13.4 \%$. This is because students lack confidence in themselves, are always dependent on friends, are less able to optimize their potential, and there are bad experiences that become obstacles. If depicted in the graph, it can be seen as follows: 


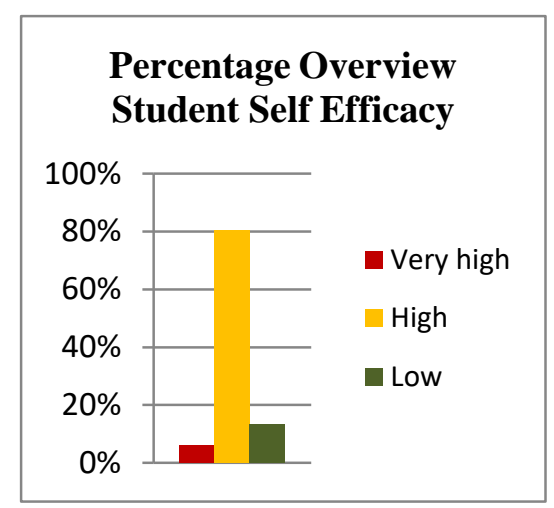

Bar graph 1 Self-efficacy of IX grade at SMP Negeri 5 Kota Serang

The graph above shows that the self-efficacy of IX at SMPN 5 Serang City in the academic year 2019/2010, which is included in the low category, is green. Therefore, follow-up must be done to obtain better results. Even though, when viewed as a whole, it is quite high. It can be seen from the yellow graph category that has a percentage of $80.3 \%$ or 90 students.

From the results of the study, Table 2 shows that there are empirical data results with scores for the distribution of self-efficacy scales of students with a total population of 112 students, then the following empirical results are obtained.

Table 2. Empirical data result

\begin{tabular}{llrr}
\hline \multicolumn{3}{c}{ Empirical } \\
\hline Min & Max & Mean & SD \\
91 & 122 & 105.33 & 10.801 \\
\hline
\end{tabular}

Furthermore, to find out the results of the hypothesis made, the study uses the Wilcoxon test and Effective Contribution.

Table 3 Wilcoxon student test results in overall pre-test and post-test

\begin{tabular}{lrrr}
\hline Explanation & $\mathrm{n}$ & Mean & Sum of Ranks \\
\hline $\begin{array}{l}\text { Post-Test } \\
\text { Pre-Test }\end{array}$ & 15 & 8.00 & 120.00 \\
\hline
\end{tabular}

Table 3 shows that from the above data, it is known that an increase in student self-efficacy, before being given a pre-test the average value of 8.00 and after carrying out sociodrama treatment treatments, the average value becomes 120.00. Furthermore, to find out how much the level of "Ubrug" Sociodrama technique in increasing students' self-efficacy, the researchers used the calculation of the effective contribution of simple linear regression. This contribution is used to see how much the contribution of the independent variable to the dependent variable. A simple linear regression test is carried out after the research instrument has been declared valid and reliable as well as normal and linear. The following results are obtained from the results of a simple linear regression test. 
Table 4 ANOVA simple linear regression test results

\begin{tabular}{lcr}
\hline Test & Df & Sig. \\
\hline Simple linear regression & 14 & 0.041 \\
\hline
\end{tabular}

It can be seen from Table 4 above that the regression test results obtained a significance level of $0.041<0.05$, then the regression model can be used to predict the sociodrama $(\mathrm{x})$ technique against the efficacy variable $(\mathrm{y})$. Regression test results obtained a significance level of 0.041 less than the significance level of 0.05 . Thus, Ha is accepted, which means there is a relationship between sociodrama techniques and self-efficacy of IX grade at SMPN 5 Kota Serang. For the results of effective contributions can be seen as follows:

Table 5 Results of effective contributions (SE)

\begin{tabular}{lrrrr}
\hline Variable & Regression Coefficient (Beta) & KoefisienKorelasi & R Square & Explanation \\
\hline $\mathrm{X}$ & 0.532 & 0.532 & 28.3 & Sign \\
\hline
\end{tabular}

From Table 5 results of these data indicate that $\mathrm{R}$ Square has a contribution to student self-efficacy of 28.3, which means that the relationship between sociodrama techniques and student self-efficacy is equal to 0.283 . To find out how much the level of "Ubrug" sociodrama techniques improve students' self-efficacy, the researchers used the effective contribution calculation of simple linear regression. This contribution is used to see how much the contribution of the independent variable to the dependent variable.

\section{Discussion}

From the post-test results for class IX students at SMP Negeri 5 Kota Serang, students experience improvement after receiving treatments in the form of sociology techniques "Ubrug". This is supported by Syaefullah and Syaefullah (2015) 's research that the results of student self-efficacy show in the high category, but several other students are included in the medium category, and that needs to be followed up. After being given treatment, it can be seen that the results of the study received an increase in the academic self-efficacy score from pre-cycle to cycle of 24.5

In this study, researchers used group guidance services using the sociodrama technique "Ubrug" as a means of increasing student self-efficacy. According to Djumhur and Moh (1975) states that group guidance is a process of providing continuous and systematic assistance to students in solving problems they face in the form of groups, self-understanding, self-acceptance, self-realization in accordance with their potential and the ability to achieve self-adaptation self-adaptive to the environment both family and community. Another elaboration is expressed by Webster and Wilson (1973) that group guidance is the process of assisting individuals shown in a group situation where members who participate in such assistance are more than two people or to prevent problems arising from students and developing student potential. Furthermore, according to Prayitno (1995) states group guidance means utilizing dynamics to achieve guidance and counseling goals. Group guidance is more of an effort to guide individuals through groups.

Furthermore, the use of sociodrama techniques, according to Romlah and Titiek (2013), is one of the role-plays aimed at solving social problems that arise in human relationships. Meanwhile, according to Telesco (2006), sociodrama can describe a theater technique (role-playing / imitating roles in real life) used in educational and 
training settings to be used as a form of therapy in training. This is in line with previous research on the effectiveness of sociodrama techniques by Djannah and Edy (2012), that from the results of the research and discussion that has been described, it can be concluded that the guidance of sociodrama technique groups is effective for increasing social interaction with peers. Winarlin, Lasan have conducted other research, and Widada (2016), they revealed that sociodrama techniques through effective group guidance to reduce students' verbal aggressive behavior. From the data obtained, there was a significant change in aggressiveness in all research subjects. Research subjects experienced a decrease in the level of aggressiveness and entered into a low classification

In this case, the provision of treatments using sociodrama techniques is based on aspects of self-efficacy consisting of aspects of the level, aspects of strength, and aspects of generality. In the process of giving sociodrama techniques, we can see significant changes experienced by students through the provision of pre-test and posttest. This is in line with Nur'aini research (2014) on "The development of a group guidance model with sociodrama techniques to improve the adjustment of Class $\mathrm{X}$ grade at Islamic Vocational School of Fairings Pringsewu-Lampung" that there was an increase between before and after treatment was given.

Something similar was experienced by researchers when students were given a post-test statement sheet. Students experience an increase when given treatments in the form of sociology techniques "Ubrug", This shows that the Influence of the administration of sociodrama "Ubrug" techniques to student self-efficacy is low. If seen from the results of the hypothesis test taken, the researcher uses the Wilcoxon test to find out the differences in filling out the questionnaire during the pre-test and post-test of the experimental group, and it is known that there is a change in the value obtained. This was revealed by (Cooper \& Schindler, 2014) that the basis for making decisions to accept or reject hypotheses could be seen by using the Wilcoxon sign rank test. From the researchers' data, it can be concluded that there is an influence of the "Ubrug" sociodrama technique on the self-self-efficacy of IX grade students at SMP Negeri 5 Kota Serang. This then makes the results and discussion to answer the researcher problem formulation.

Sociodrama is one of the techniques of group counseling services that allows many students to jointly obtain various materials from certain sources (especially supervisors or counselors) that are useful to support the daily lives of individuals as students, family members and the community discussing educational, work, personal and social problems. According to Sudjana (2005), sociodrama is the dramatization of behavior in relation to social problems. According to Romlah and Titiek (2013) suggested that sociodrama is playing a role aimed at solving social problems that arise in relationships between people. In this study, researchers used the sociology technique "Ubrug" to improve student self-efficacy.

Bandura (1997) in social cognitive theory, explains that students' low self-efficacy will cause increased anxiety and avoidance behavior. Individuals will avoid activities that aggravate the situation, threats do not cause this, but because they feel they cannot manage the aspects at risk. Bandura also added that self-efficacy is one of the potentials in human cognitive factors because it is very influential on every human being's behavior. Self-efficacy also illustrates how people feel, think, motivate themselves, and behave. 
According to Bandura (1997)) states that self-efficacy can be obtained, studied and developed from four sources of information, namely: (1) results achieved by students, (2) self-experience, (3) social persuasion, and (4) circumstances emotional/physical. In comparison, Efforts in seeing students' self-efficacy can be seen from 3 levels of aspects, namely: (1) the level of difficulty of the task, (2) the strength of confidence, and (3) generality.

This illustrates that through the treatment carried out, students feel happy to learn while playing roles outside the classroom to increase self-efficacy. This is in line with Mahardika (2019) research, namely that the Influence of sociodrama techniques on students' self-efficacy in academic matters. He also revealed that using this sociodrama technique provides opportunities for children to play an active role in dramatizing a social problem, which simultaneously trains their courage and ability to carry out a plan in front of many people. So the purpose of this study was to determine the Influence of sociodrama techniques on the academic self-efficacy of $\mathrm{X}$ grade at Administrasi Perkantoran (APk) SMK Pemuda Papar.

Based on the results of the analysis of student self-efficacy before treatment is included in the low category. But after being given a sociodrama technique, the students experienced an increase so that it was included in the high and very high categories. Based on the results of the analysis shows that there are differences in self-efficacy before and after treatment. The ability of self-efficacy of students after. Then there is the Influence of sociodrama techniques on students 'self-efficacy, it can be seen from the increase in students' self-efficacy scores after being given treatments. The results showed differences in students' self-efficacy scores before and after the "Ubrug" sociodrama treatment.

On the other hand, researchers also found that treatment using the sociodrama technique "Ubrug" can affect student self-efficacy. This is in line with research by Anggara, Yusuf, and dan Marjohan (2016) concludes that group guidance with modeling effectively increases self-efficacy in facing exams. Regarding the ability of self-efficacy students must continue to be improved again because with self-efficacy students will gain more knowledge about self-understanding, be able to appreciate their abilities, develop their interests and talents and will provide convenience for students themselves. Based on the research results, it turns out there is an influence from the administration of the sociodrama technique "Ubrug" to the self-efficacy of IX grade students at SMP Negeri 5 Kota Serang.

According to Bandura (1997), several factors can influence student self-efficacy, namely: (1) Experience in charge of something, (2) Social Modeling, (3) Social Persuasion, (4) Physical and emotional conditions. Therefore, further studies related to this research are needed to pay attention to other variables such as student interest in learning and student motivation. The implementation of treatments was carried out as a group of 15 students without restrictions on the variable distractor. Then it is possible the Influence of other distractors in the environment that can affect respondents. Based on the description, it can be said that the provision of sociodrama techniques, "Ubrug" can improve the self-efficacy of IX grade students at SMP Negeri 5 Kota Serang. 


\section{Conclusion}

\section{Conclusion and Recommendation}

Based on the explanation above, this study shows an increase in students' selfefficacy after treatment using the "ubrug" sociodrama technique. There are still some students who have low self-efficacy due to a lack of self-confidence. This proves that providing sociodrama "ubrug" techniques can improve students' self-efficacy.

\section{Recommendation}

From the results of the research, it is expected that the school will work together to provide direction and encouragement to students to foster a sense of confidence in students. Students can optimize their abilities in the academic and non-academic fields. The results of this study can also be used as reference material for further researchers in further study of student self-efficacy, and are expected to conduct further research on other variables that can affect student self-efficacy compared to other groups in subsequent studies.

\section{References}

Alwisol. (2009). Psikologi Kepribadian. Malang (ID): UMM Press

Anggara, F., Yusuf, A., M., \& Marjohan. (2016). Efektivitas layanan bimbingan kelompok dengan modeling dalam meningkatkan efikasi diri siswa dalam menghadapi ujian. Jurnal Konselor, 5(1), 42-49.

Bandura, A. (1986). Social foundations of thought and action. Englewood Cliffs, NJ: Prentice Hall.

Bandura, A. (1997). Self-efficacy: The exercise of control. New York (US): Freeman and Company.

Blatner, A. (2006). Enacting the new academy: Sociodrama as a powerful tool in higher education. ReVision: A Journal of Consciousness \& Transformation, 28 (1), 2036

Cooper, \& Schindler. (2014). Bussiners Research Method. New York(US): McGrawHill

Darajat, Z. (2011). Metodik Khusus Pengajaran Agama Islam. Jakarta(ID): Bumi Aksara.

Djannah. W., \& Edy. D. (2012). Bimbingan Kelompok Teknik Sosiodrama Untuk Meningkatkan Interaksi Sosial Dengan Teman Sebaya. Universitas Sebelas Maret, Jurnal Bimbingan. 1(2), 145-165

Djumhur, \& Moh, S. (1975). Bimbingan dan Penyuluhan di Sekolah. Bandung(ID): CV Ilmu.

Eckloff, \& Maurine. (2006). Using Sociodrama to Improve Communication and Understanding. Etcetera: A Review of General Semantics. 63(3), 259-269

Gay, L. R., \& Diehl, P. L. (1992). Research Methods for Business and Management. . New York(USA): MacMillan Publishing Company

Humeira, Y. (2014). Keefektifan layanan bimbingan kelompok dengan teknik bermain pean untuk meningkatkan efikasi diri dalam belajar siswa kelas VIII SMP Negeri 5 Surakarta. [Skripsi]. Program Studi Bimbingan dan Konseling. Universitas Sebelas Maret: Tidak Diterbitkan.

Hurlock, E. B. (1980). Psikologi Perkembangan: Suatu Pendekatan Sepanjang Rentang Kehidupan. Jakarta(ID): Gramedia.

Lahey, B. (2004). Psychology An Introduction. New York(USA): McGraw Hill Companies Inc 
Mahardika, S. (2019). Pengaruh teknik sosiodrama terhadap efikasi diri akademik siswa kelas X Aministrasi Perkantoran (APk) SMK Pemuda Papar. Skripsi. Program Studi Bimbingan dan Konseling. Universitas Nusantara PGRI Kediri: Tidak Diterbitkan

Mahmudi, M. H., \& Suroso. (2014). Efikasi diri, dukungan sosial, dan penyesuaian diri dalam belajar. Jurnal Psikologi Indonesia, 3(2), 183 -194.

Nur'aini, E. P. (2014). Pengembangan model bimbingan kelompok dengan teknik sosiodrama untuk meningkatkan penyesuaian diri siswa. Jurnal Bimbingan Konseling, 3(2), 109-110

Prasetya, D. (2019, October 4). Gelar sidak, Wali Kota Serang temukan pelajar merokok di warkop saat jam belajar. Diakses dari https://www.merdeka.com/peristiwa/gelar-sidak-wali-kota-serang-temukanpelajar-merokok-di-warkop-saat-jam-belajar.html

Prayitno. (1995). Layanan Bimbingan dan Konseling Kelompok Dasar Dan Profil. Jakarta(ID): Rineka Cipta

Romlah, \& Tatiek. (2013). Teori dan Praktek Bimbingan dan Konseling Kelompok. Malang (ID): Universitas Negeri Malang Press

Sanjaya, H. W. (2012). Strategi Pembelajaran Berorientasi Standar Proses Pendidikan, Jakarta(ID): Kencana Prenada Media Group

Seha, N., Bachtiar, A., Oktaviantina, A. D., Rukmini, \& Sehabudin (2014). Fungsi teater rakyat ubrug bagi mahasiswa Banten. Jurnal Atavisme Edisi 2014, 17(1), 108-109. Doi: 10.24257/atavisme.v17i1.23.107-120

Sekaran, Uma, \& Bougie, R. (2017). Metode Penelitian untuk Bisnis Pendekatan Pengembangan-Keahlian. Jakarta(ID): Salemba Empat.

Sudjana, N. (2005). Dasar-Dasar Proses Belajar Mengajar. Bandung(ID): Sinar Baru Algesindo.

Sugiyono. (2017). Metode Penelitian Kuantitatif, Kualitatif, dan R\&D. Bandung(ID): CV Alfabeta.

Syaefullah, \& Syaefullah, I. (2015). Upaya meningkatkan efikasi diri akademik melalui diskusi kelompok pada siswa kelas VIII di SMP Negeri 3 Bukateja Purbalingga. [Skripsi]. Program Studi Psikologi Pendidikan dan Bimbingan. Universitas Negeri Yogyakarta: Tidak Diterbitkan

Telesco, G. A. (2006). Using sociodrama for Radical Pedagogy: Methodology for Education and Change. Journal American Intercontinental University, 8(2), 1

Webster, C.C. \& P.N Wilson. (1973). Agriculture in The Tropic. London: Iowe and Brydone Ltd.

Winarlin, R., Lasan, B. B., \& Widada (2016). Efektivitas teknik sosiodrama melalui bimbingan kelompok untuk mengurangi perilaku agresif verbal siswa SMP. Jurnal Kajian Bimbingan dan Konseling, 1(2), 68-73. eISSN: 2503-3417

Winkel, W. S. (1993). Psikologi Pendidikan dan Evaluasi Belajar. Jakarta(ID): Gramedia

Wirawan, S., \& Eko, A. (2009). Psikologi sosial. Jakarta(ID): Salemba Humanika

Wood, R. E., \& Bandura, A (1989). Social cognitive theory of organizational management. Academy of Management Review, 14(3), 361-384. DOI: 10.5465/AMR.1989.4279067

Yusuf, A. M. (2016). Metodologi Penelitian Kuanti, Kuali dan Penelitian Gabungan. Jakarta(ID): Prenada Media Group. 